\title{
Corrosion Behavior of Nickel Alloys NiFe and NiCu Welding on Base Metal in Alkalie Solution
}

\author{
Eltohamy.R. Elsharkawy ${ }^{1}$,Amany NagyKamel ${ }^{1}$, A. F. Waheed ${ }^{2}$ \\ ${ }^{1}$ Quality control and quality assurance departmentEgyptian nuclear and radiological regulator \\ authority (ENRRA) \\ Metallurgy Department, Nuclear Research Center, Atomic Energy Authority, Cairo, Egypt
}

Clading metal weld is a composite product developed to provide effective and economic utilization of expensive materials. The welding layer $\mathrm{NiCu}$ and $\mathrm{NiFe}$ that will be in contact with the corrosive media is made of the corrosion resistant alloys, whilst the less expensive base carbon steel covers the strength and toughness required to maintain the mechanical integrity. In a nuclear power plant clading metal weld joints are necessary for joining the different materials chosen for the various parts of the heat transfer circuit. Also Clading metal welds are utilized in processing pressure vessels, heat exchangers, tanks and storage facilities. Anodic polarization curves for deposited as weld and heat treated Ni alloy weld metal in $3.5 \% \mathrm{NaCl}$ solution with alkaline $\mathrm{pH}$ are studying. Anodic polarization curve for $\mathrm{NiFe}$ weld metal on carbon steel heat treated for 50,500 and $1000 \mathrm{hr}$ at $550 \mathrm{oC}$ are recorded. The results indicated that, for example, the anodic polarization curve for $\mathrm{NiFe}$ weld metal heat treated for $500 \mathrm{hr}$ at $550 \mathrm{oC}$ in $3.5 \% \mathrm{NaCl}$ solution, the corrosion current density was $11.23 \mu \mathrm{A} / \mathrm{cm} 2$ .The corrosion current density increase at constant rate which indicate a uniform corrosion. The hardness is $205 \mathrm{Hv}$ measured at 300 gmload.As for the anodic polarization curve for Ni$\mathrm{Cu}$ weld metal heat treated for $500 \mathrm{hr}$ at $550{ }^{\circ} \mathrm{C}$ tested in $3.5 \% \mathrm{NaCl}$ solution, the corrosion current density was $28.42 \mu \mathrm{A} / \mathrm{cm} 2$. The corrosion current density increases after that with constant rate till and of the experiment. The hardness is $235 \mathrm{Hv}$ measured at $300 \mathrm{gm}$ load.

\section{1-Introduction}

The weld metal composition is usually not uniform, particularly with multiple pass welds, and a composition gradient is likely to exist in the weld metal adjacent to each base metal. These solidification characteristics of the weld metal are also influenced by the relative dilutions and the composition gradients near each base metal[1,2]. These characteristics are important with respect to hot cracking of the weld metal during solidification. Also specimens from dissimilar metal welds of different types of electrodes between 304L stainless steels and pressure vessel welded joints, were manufactured. Different welding electrodesNiFe, $\mathrm{Ni}$ and $\mathrm{NiCu}$ nickel base alloy were used[3,4]. These types of claddedcarbon steel and weld joints are widely used in the nuclear power, chemical and petrochemical industries. Investigations of potential degradation mechanisms, integrity assessment methods have been performed in many developments nuclear centers[5].The weld should have a corrosion / oxidation resistance more that the least resistant base metal being joined. It is fortunate that in most all instances the weld will be of a higher alloy content (better corrosion and oxidation resistance) than the least resistant base metal being joined $[6,7]$.

Some of these specimens were heat treated at temperatures $550^{\circ} \mathrm{C}$ for various holding times, ranging from 50 to 1000 hours, $550^{\circ} \mathrm{C}$ is selected because it is within range of nominal operating temperature[8,9].The experimental investigation included corrosion test and 
hardness for weld joints.Nickel alloys are a viable solution for enhancing corrosion properties due to its excellent resistance toaqueous corrosion[10].

For corrosion applications (anodic protection), high density and low oxide content are among the most important properties which the coating has to attain in order toguarantee the high corrosion resistance[11,12]. A fully dense coating forms a physical barrierwhich in turn, prevents electrolyte penetrating through the coating and reacting with the steel substrate which would otherwise result in the formation of voluminous corrosion which products are likely to cause coating failure. Hence, great effort has been made inorder to achieve dense and oxide-free $\mathrm{Ni}$ and $\mathrm{NiCu}$ coatings. Several studies on themicrostructure of cold-sprayed $\mathrm{Ni}$ and $\mathrm{NiCu}$ coatings have reported high denseness withacceptable bond strengths $[13,14]$.

\section{2-Experimental work}

The experimental investigation was carried out to evaluate the corrosion performance of two types of weldments using manual shielded metal arc welding processes.Manual shielded metal arc welding (SMAW) process was used to prepare weldmentsdepositing layers.

\subsection{Types of electrodes}

Two types of coated electrodes of class AWS (American Welding Society) were used in the welding experiments. The types is $\mathrm{E}-\mathrm{NiFe}$ and, $\mathrm{E}-\mathrm{NiCu}$ with diameter $\phi=4 \mathrm{~mm}$. The chemical composition of the used electrodes is shown in Table (1)

Table (1) Chemical composition of the electrode

\begin{tabular}{|c|c|c|c|c|c|c|c|c|c|}
\hline Element & $\mathrm{C}$ & $\mathrm{Si}$ & $\mathrm{Mn}$ & $\mathrm{Cr}$ & $\mathrm{Cu}$ & $\mathrm{Ni}$ & $\mathrm{Mo}$ & $\mathrm{Ti}$ & $\mathrm{Fe}$ \\
\hline $\mathrm{NiFe}$ & 1 & $<2.0$ & $<1.0$ & - & - & 56 & - & - & Basis \\
\hline $\mathrm{NiCu}$ & 0.05 & 0.7 & 3.5 & - & 29 & bal & - & 0.4 & 1.3 \\
\hline
\end{tabular}

\subsection{Heat treatedprocedure}

Weld metalspecimens were subjected to an heat treated temperature of $550^{\circ} \mathrm{C}$ for various holding times ranging from 50 to 1000 hours, followed by air-cooling, in order to simulate working conditions. The effect of this isothermal heat treated on microstructure was investigated for weld metal samples. Theheat treated process was performed in a muffle furnace, which is automatically controlled with an accuracy of $\pm 5^{\circ} \mathrm{C}$. An additional NiNiCrthermCouple attached to a digital thermal indicator was used to check the temperatures of the furnace throughout the holding time.

\subsection{Metallographic examination}

Metallographic examination was carried out for the weld deposits. Variations of microstructure in dissimilar metal welds $\mathrm{NiFe}$ and $\mathrm{NiCu}$ for as weld conditions and after heat treated was examined.The specimens were ground under water on rotating disc, using abrasive paper with grades ranging from 180 to 2000. Then polished to mirrored surface by using diamond paste with grades 3 and 1 micron. Nickel alloys were etched with $30 \mathrm{ml} \mathrm{HNO}_{3}$ and $70 \mathrm{ml} \mathrm{H} \mathrm{H}_{2} \mathrm{O}$ by immersion at room temperature for 5 to 20 secondSpecimens were rinsed with alcohol and dried with hot air. The optical microscope(OM) was used for microstructural examination. 


\subsection{Microhardness test}

A Vickers microhardness testing machine was used to measure at least sevenhardness values on the weld deposit specimens in the as weld and after heat treatment conditions. The applied load was $300 \mathrm{gm}$ and the indentation time was 30 second.

\subsection{Electrochemical Corrosion testing}

Prior to corrosion behavior studies, the samples were ground on $\mathrm{SiC}$ grinding papers from 240 till 1000 grade, followed by polishing on polishing lapped cloth using $1 \mu \mathrm{m}$ diamondsuspension. Then the polished samples were degreased with ethanol before immersion in thetest solution.The electrochemical corrosion behavior of the samples was studied by applying thepotentiodynamic polarization technique using a potentiostat (Electrochemical ImpedanceAnalyzer, Model 6310) interfaced to a computer and a threeelectrode cell with the sample asa working electrode of exposed area $100 \mathrm{~mm}^{2}$, a saturated calomel reference electrode (SCE).For testing the performance of the deposted $\mathrm{Ni}$ alloysNiFe and $\mathrm{NiCu}, 3.5 \% \mathrm{NaCl}$ solution was used, the solution was prepared from reagent $\mathrm{NaCl}$ salt, the $\mathrm{pH}$ of the solution is nearly alkaline.

\section{3-Results and Discussions}

Figure(1)showing the microstructure features of NiFe weld metal deposited on carbon steel (a)as weld (b) hert treated for $50 \mathrm{hr}$ (c) hert treated for $500 \mathrm{hr}$ and (d) hert treated for $1000 \mathrm{hr}$. These specimens exhibit a complex precipitation behavior at elevated temperatures, during welding, furthermore, the precipitation behavior will depend upon the carbon content and the final temperature[15].This reveals an almost dendritic morphology structure with a region in the weld metal exhibiting more ferritic-austenitic modes of solidifications. The regions solidified in the ferritic-austenitic mode and consisting of small amount of delta ferrite,segregated in interdendritic (or intercellular) boundaries[16-10].

Figure(2) showing the microstructure features of $\mathrm{NiCu}$ weld metal deposited on carbon steel (a)as weld (b) hert treated for $50 \mathrm{hr}$ (c) hert treated for $500 \mathrm{hr}$ and (d) hert treated for 1000 hr.Morphology showed a bi-modal layer formation where white phaseshowed a transition fromsmall spherical shape to dendritic and cauliflower shape with application of ultrasound[17].
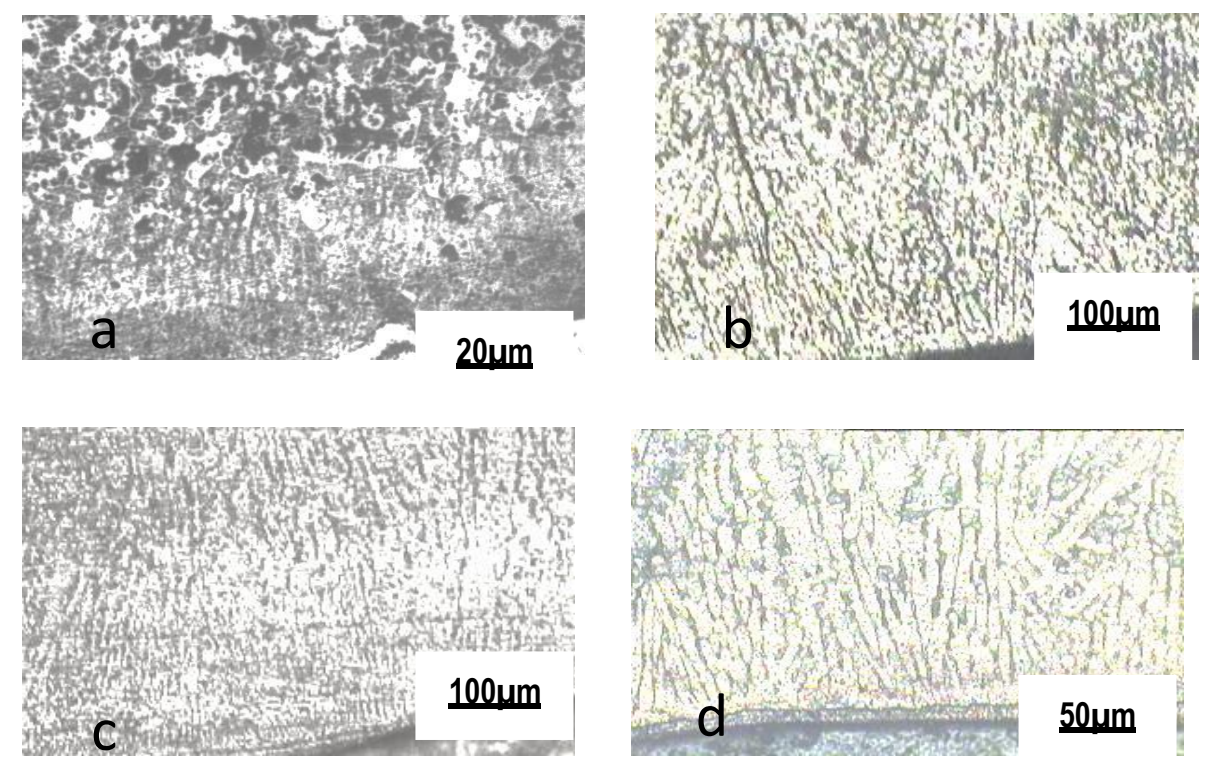

Figure(1) Optical micrograph showing the microstructure features of NiFe weld metal deposited on carbon steel and after heat teated(a) as weld (b) $50 \mathrm{hr}$ (c) $500 \mathrm{hr}$ and (d) $1000 \mathrm{hr}$ 

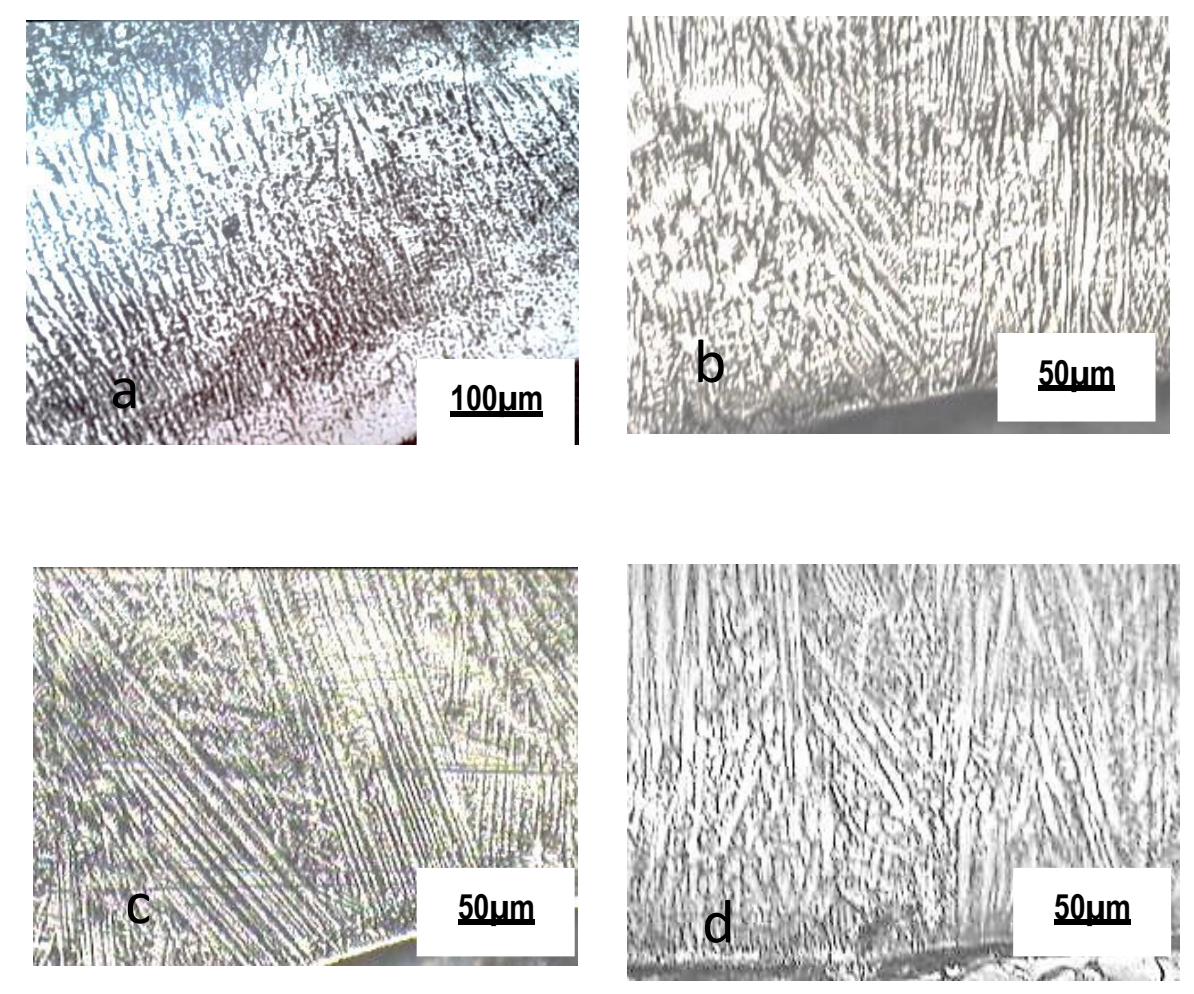

Figure(2) Optical micrograph showing the microstructure features of $\mathrm{NiCu}$ weld metal deposited on carbon steel and after heat teated(a) as weld (b) $50 \mathrm{hr}$ (c) $500 \mathrm{hr}$ and (d) $1000 \mathrm{hr}$

The average values of microhardness testing measuring is shown in Table (2) for as-welded condition and after heat treated at $550^{\circ} \mathrm{C}$ for $50 \mathrm{hr}, 500 \mathrm{hr}$ and 1000 $\mathrm{hr}[16]$.Thehighestmicrohardness values $(258 \mathrm{Hv})$ for as weld condition of NiFeand the smallest $(153 \mathrm{Hv})$ after heat treated for $1000 \mathrm{hr}$ may be attributed to the strain hardening that produces large amount of deformation twins or due to coarsening of precipitates.

For $\mathrm{NiCu}$ the lowest microhardness values for as weld condition $(170 \mathrm{Hv})$ and the hightest at $500 \mathrm{hr}(235 \mathrm{Hv})$,Shuangqun Zhao et al [18] found that room temperature microhardness of the alloy decreased with an increase in temperature mainly due to the growth of $\gamma^{\prime}$ phases. Elevated-temperature microhardness of the alloy for standard heat-treated condition was higher than room temperature microhardness.

Table ( 2 ) The average valuesof microhardness testing measuring $(\mathrm{Hv})$

\begin{tabular}{|c|c|c|c|c|}
\hline & as weld & $50 \mathrm{hr}$ & $500 \mathrm{hr}$ & $1000 \mathrm{hr}$ \\
\hline $\mathrm{NiFe}$ & 258 & 197 & 205 & 153 \\
\hline $\mathrm{NiCu}$ & 170 & 213 & 235 & 217 \\
\hline
\end{tabular}

The corrosion current density $\mathrm{I}_{\text {corr }}$ and corrosion potential $\mathrm{E}_{\text {corr }}$ of $\mathrm{NiFe}$ and $\mathrm{NiCu}$, which were determined by potentiodynamic techniqueTable(3). From these data, one may generally evaluate the corrosion perfomance of $\mathrm{NiFe}$ and $\mathrm{NiCu}$ at differentheat treated conditions . 
Table ( 3 )Corrosion potential $E_{\text {corr }}$ and corrosion current density $I_{\text {corr }}$ for NiFeand NiCu

\begin{tabular}{|c|c|c|c|c|}
\cline { 2 - 5 } \multicolumn{1}{c|}{} & \multicolumn{2}{c|}{$\mathrm{NiFe}$} & \multicolumn{2}{c|}{$\mathrm{NiCu}$} \\
\hline $\begin{array}{c}\text { heat treated } \\
\text { condition }\end{array}$ & $\mathrm{E}_{\text {corr }}(\mathrm{mV})$ & $\mathrm{I}_{\text {corr }}\left(\mu \mathrm{A} / \mathrm{cm}^{2}\right)$ & $\mathrm{E}_{\text {corr }}(\mathrm{mV})$ & $\mathrm{I}_{\text {corr }}\left(\mu \mathrm{A} / \mathrm{cm}^{2}\right)$ \\
\hline As weld & -362.1 & 5.737 & -375.8 & 15.06 \\
\hline $50 \mathrm{hr}$ & -506.3 & 6.570 & -428.9 & 17.09 \\
\hline $500 \mathrm{hr}$ & -436.9 & 11.23 & -484.6 & 28.42 \\
\hline $1000 \mathrm{hr}$ & -446.5 & 6.364 & -446.6 & 21.54 \\
\hline
\end{tabular}

The electrochemical tests were established by using Potentiodynamic technique. Anodic polarization curves for deposited as weld and heat treated for $\mathrm{NiFe}$ weld metal in $3.5 \%$ NaClsolution having nearly neutral $\mathrm{pH}$ are shown in Figures (3-6).

Figure(3) shows the anodic polarization of Ni-Fe as the weld metalin 3.5\% NaClsolution,the corrosion current density is $5.737 \mu \mathrm{A} / \mathrm{cm}$. The current density increases in slow rate till the potential is $-300 \mathrm{mV}$, then it increases a high rate till the end of the experiment. The hardness is $258 \mathrm{Hv}$ measured at load $300 \mathrm{gm}$ load.

Figure (4) shows the anodic polarization of Ni-Fe welds metal heat treated for $50 \mathrm{hr}$ at $550{ }^{\circ} \mathrm{C}$ in $3.5 \%$ NaCsolution, the corrosion current density is $6.570 \mu \mathrm{A} / \mathrm{cm}^{2}$. The corrosion current density increases with constant rate until $-300 \mathrm{mv}$ potential, then the current density increases with higher rate until the end of the experiment. The hardness is $197 \mathrm{Hv}$ measured $300 \mathrm{gm}$ load.

Figure (5) shows the anodic polarization curve of Ni-Fe welds metal heat treated for 500 hrat $550^{\circ} \mathrm{C}$ in $3.5 \% \mathrm{NaCl}$ solution, the corrosion current density is $11.23 \mu \mathrm{A} / \mathrm{cm}^{2}$. The corrosion current density increase at constant rate which may indicate a uniform corrosion. The hardness is $205 \mathrm{Hv}$ measured at 300 gm load.

Figure(6) gives the corrosion behavior of Ni-Fe welds metal heat treated for $1000 \mathrm{hr}$ at $550^{\circ} \mathrm{C}$ tested in $3.5 \% \mathrm{NaCl}$ solution, the corrosion current density is $6.364 \mu \mathrm{A} / \mathrm{cm}^{2}$. The corrosion current density increases smoothly without any change in the rate; this indicates uniform corrosion and no pitting behavior. The hardness is $153 \mathrm{Hv}$ measured at $300 \mathrm{gm}$ load.

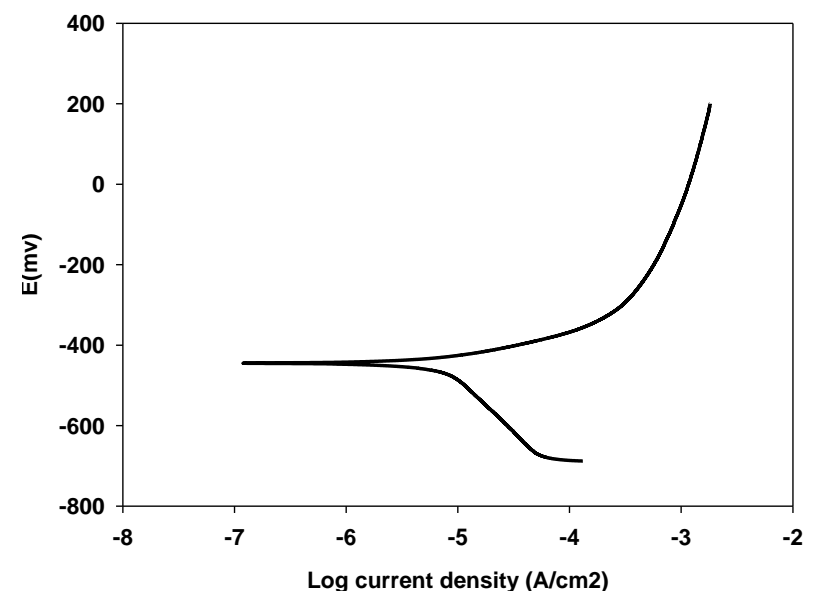

Figure(3) Anodic polarization curve of deposit NiFe welds metal for as weld condition 


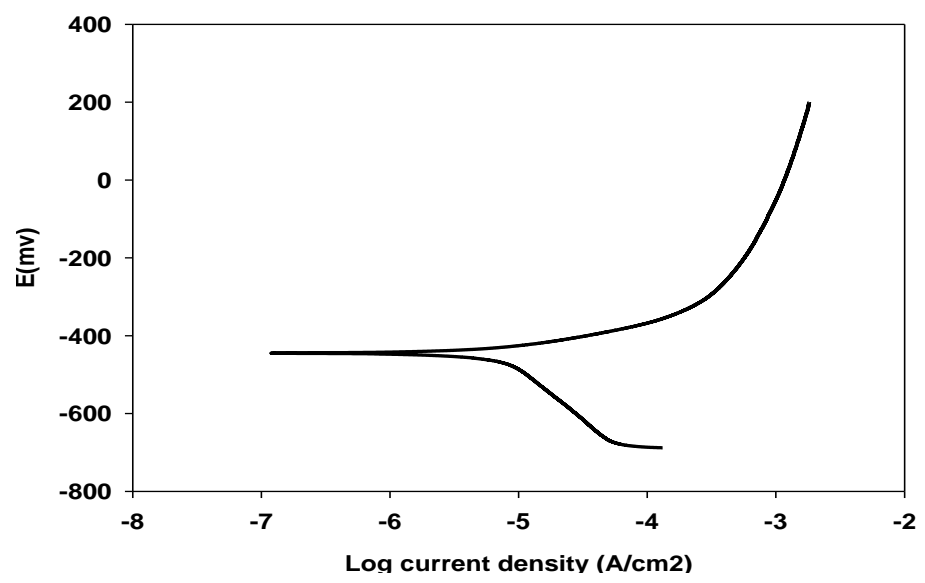

Figure(4) Anodic polarization curve of deposit $\mathrm{Ni}$ Fe weld metal heat treated for $50 \mathrm{hr}$ at $550^{\circ} \mathrm{C}$

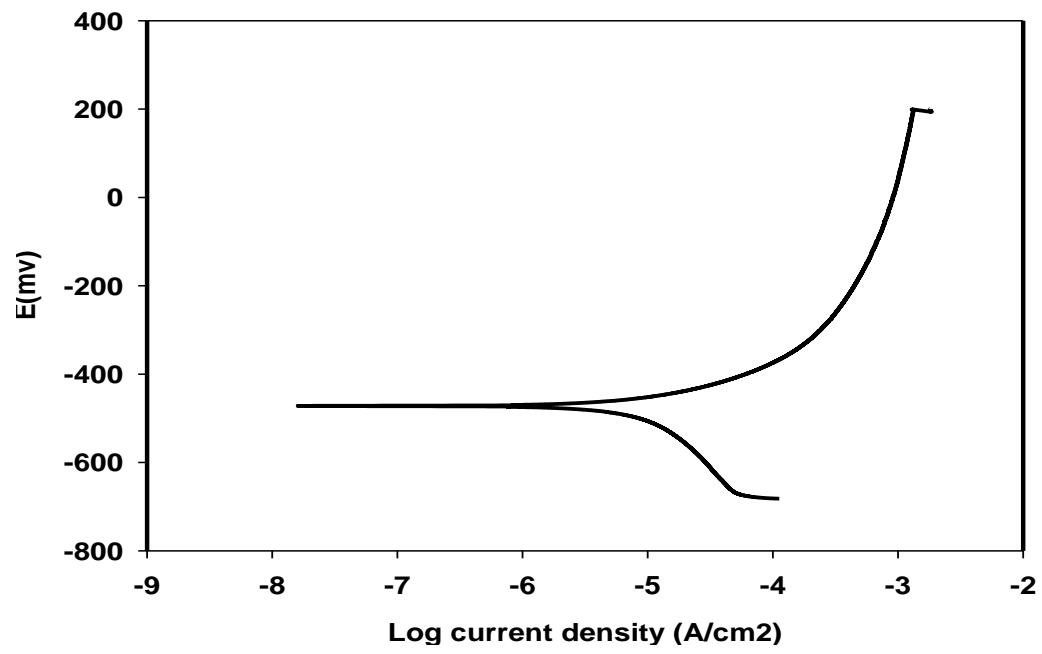

Figure (5) Anodic polarization curve of deposit Ni Fe welds metal heat treated for $500 \mathrm{hr}$ at $550^{\circ} \mathrm{C}$

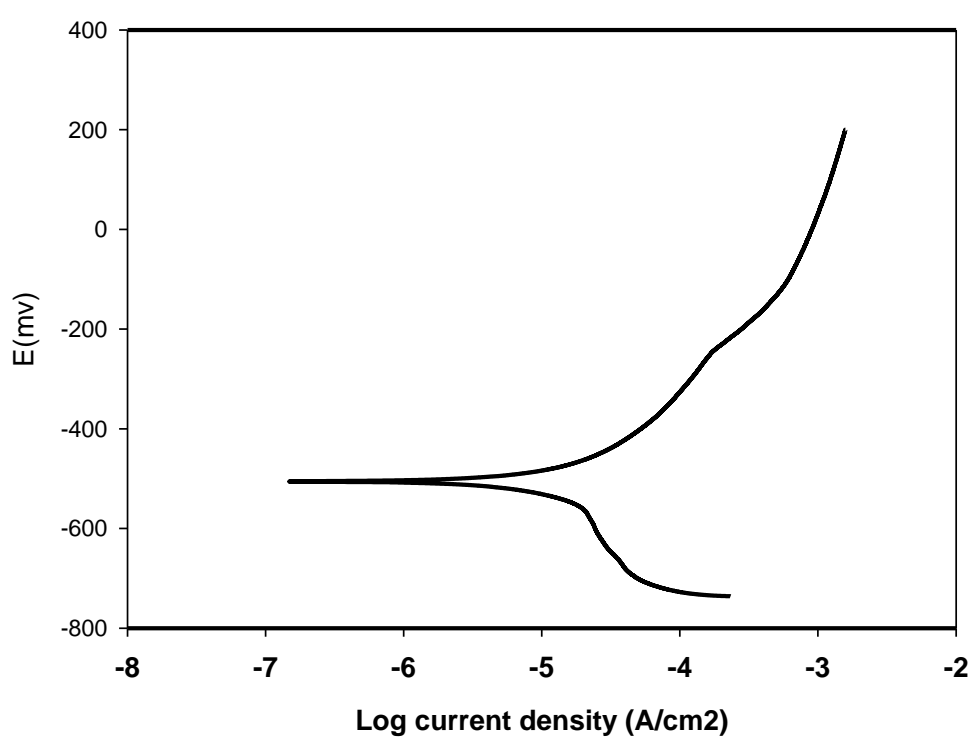

Figure (6) Anodic polarization curve of deposit $\mathrm{Ni}$ Fe welds metal heat treated for $1000 \mathrm{hr}$ at $550^{\circ} \mathrm{C}$ 
Anodic polarization curves for deposited as weld and heat treated for $\mathrm{NiCu}$ weld metal in $3.5 \%$ NaClsolution having nearly neutral $\mathrm{pH}$ are shown in Figures (7-10)

Figure (7) shows the anodic polarization curve for Ni-Cuwelds metal as welled tested in $3.5 \%$ $\mathrm{NaCl}$ solution, the corrosion current density was $15.06 \mu \mathrm{A} / \mathrm{cm}^{2}$. The corrosion current density increases at a constant rateof potential higher than corrosion potential till-300mv, then the corrosion current density increases at the higher rate till $-50 \mathrm{mV}$. After - $50 \mathrm{mV}$ the current density increases suddenly from $10^{-3} \mathrm{~A} / \mathrm{cm}^{2}$ to $10^{-2} \mathrm{~A} / \mathrm{cm}^{2}$ which may indicate a localized corrosion mechanism. After that the current density increases with regulatedbehavior which can be due to the presence of pits. Hardness is $170 \mathrm{Hv}$ measured at $300 \mathrm{gm}$ load.

Figure(8) shows the curve of anodic polarization of $\mathrm{Ni}-\mathrm{Cu}$ weld metal heat treated for $50 \mathrm{hr}$ at $550{ }^{\circ}$ Ctested in $3.5 \% \mathrm{NaCl}$ solution, the corrosion current density was $6.364 \mu \mathrm{A} / \mathrm{cm}^{2}$. The corrosion current density increases smoothly at constant rate up to $-300 \mathrm{mV}$, then increased at higher rate to $-100 \mathrm{mV}$. A sudden increases in current density in the range $3.5 \mu \mathrm{A} / \mathrm{cm}^{2}$ to $2.5 \mu \mathrm{A} / \mathrm{cm}^{2}$ which may show formation of localized corrosion, after that current density increases at high rate with irrigation. The hardness is $213 \mathrm{Hv}$ measured at $300 \mathrm{gm}$ load.

Figure (9) shows the anodic polarization curve for $\mathrm{Ni}-\mathrm{Cu}$ welds metal heat treated for $500 \mathrm{hr}$ at $550{ }^{\circ}$ Ctested in $3.5 \% \mathrm{NaCl}$ solution, the corrosion current density was $28.42 \mu \mathrm{A} / \mathrm{cm}^{2}$. The corrosion current density increases after that with constant rate till and of the experiment.The hardness is $235 \mathrm{Hv}$ measured at $300 \mathrm{gm}$ load .

Figure(10) shows the anodic polarization curve of $\mathrm{Ni}-\mathrm{Cu}$ weld metal heat treated at 1000 hrtested in $3.5 \% \mathrm{NaCl}$ solution, the corrosion current density was $21.54 \mu \mathrm{A} / \mathrm{cm}^{2}$. The corrosion current density increases with constant rate, which indicate uniform corrosion. The hardness is $217 \mathrm{Hv}$ measured $300 \mathrm{gm}$ load.

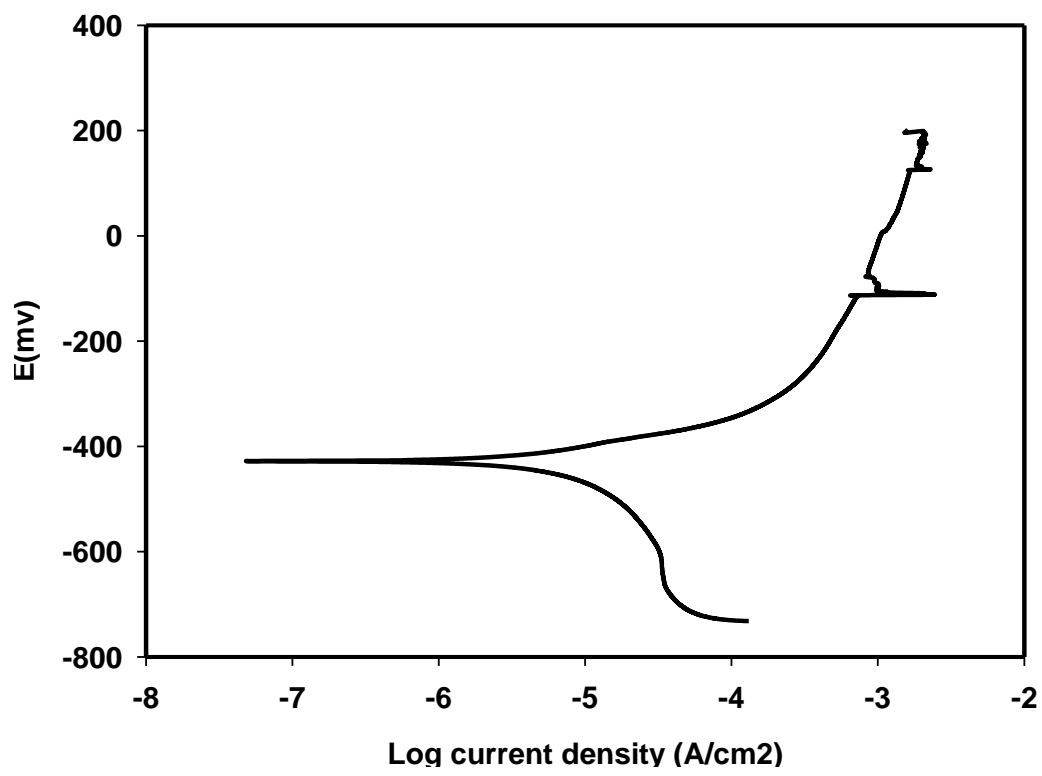

Figure (7) Anodic polarization curve of deposit $\mathrm{NiCu}$ weld metal foras weld condition 


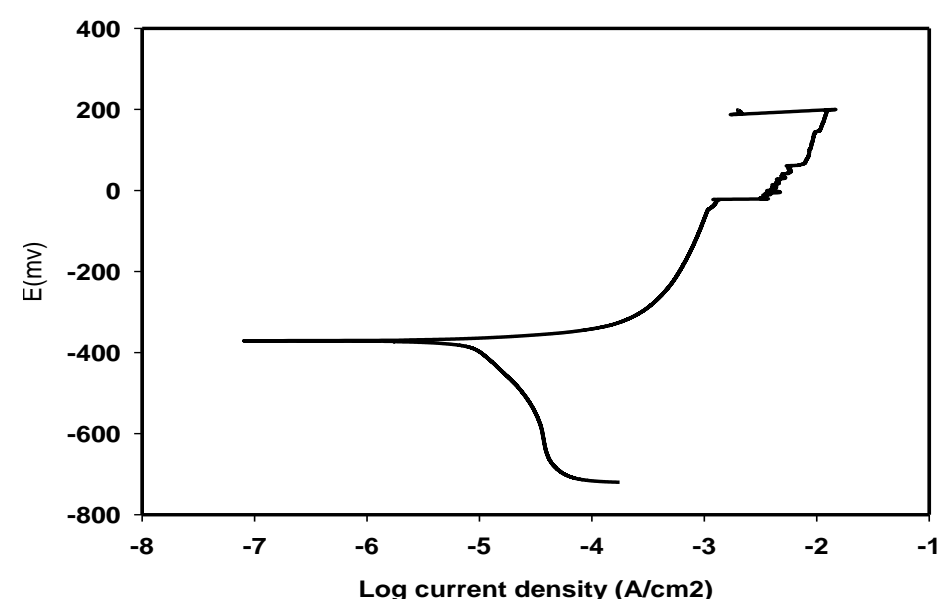

Figure (8) Anodic polarization curve of deposit $\mathrm{Ni} \mathrm{Cu}$ weld metal heat treated or $50 \mathrm{hr}$ at $550^{\circ} \mathrm{C}$

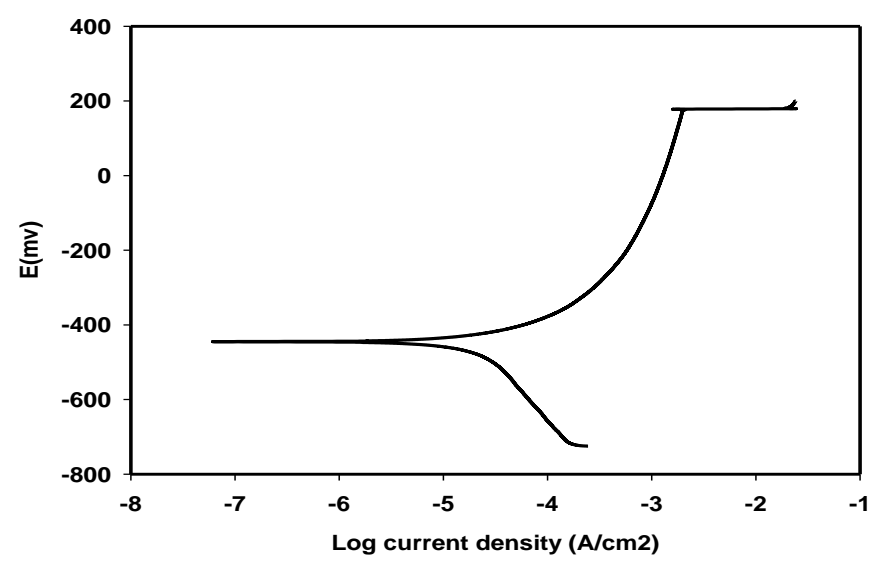

Figure(9) Anodic polarization curve of deposit $\mathrm{Ni} C \mathrm{Cu}$ weld metal heat treated for $500 \mathrm{hr}$ at $550^{\circ} \mathrm{C}$

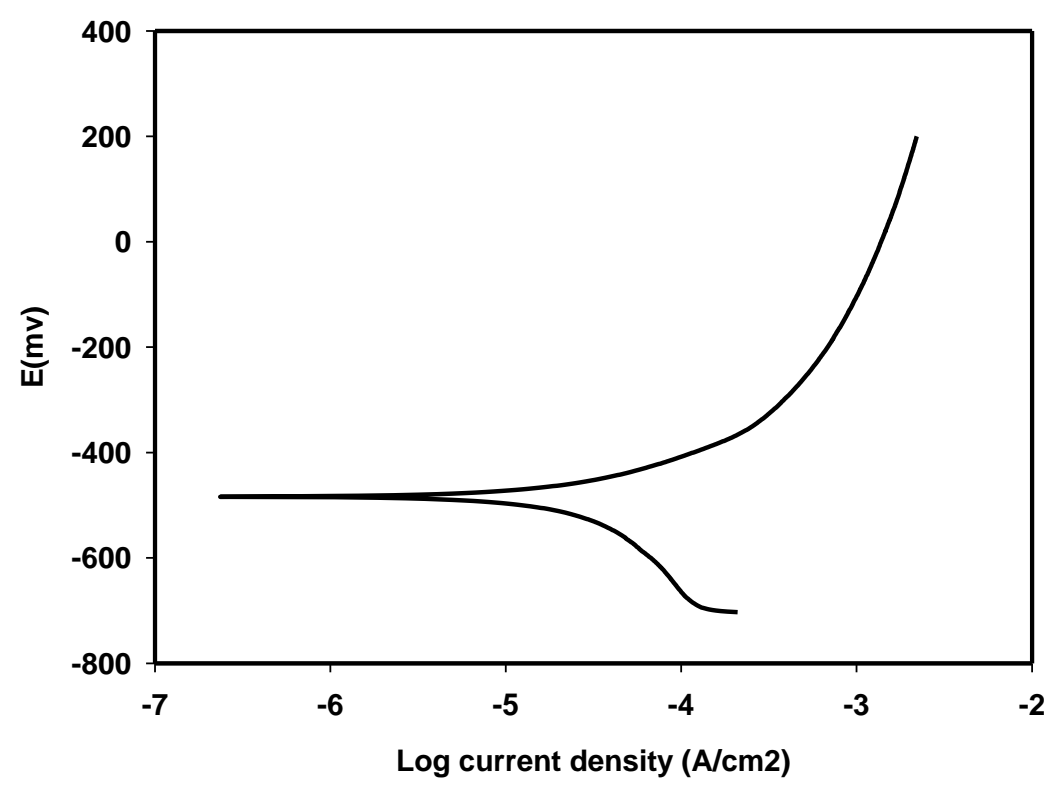

Figure (10) Anodic polarization curve of deposit $\mathrm{Ni} \mathrm{Cu}$ weld metal heat treatedor $1000 \mathrm{hr}$ at $550^{\circ} \mathrm{C}$ 


\section{General Conclusion:}

The power generation industry uses clading metal welding extensively to reduce material costs and enhance performance in elevated-temperature applications. Anodic polarization curves for deposited as weld and heat treated $\mathrm{Ni}$ alloys $\mathrm{NiFe}$ and $\mathrm{NiCu}$ weld metal in $3.5 \%$ $\mathrm{NaCl}$ solution havingalkaline $\mathrm{pH}$ werestudied.Anodic polarization curve for $\mathrm{Ni}$ alloys weld metal heat treated for 50,500 and 1000 hours at $550 \mathrm{C}^{\mathrm{o}}$, are recorded. The results indicated that, the corrosion current density of the anodic polarization curve forboth $\mathrm{NiFeand} \mathrm{NiCu}$ alloys decreased at heated treated time $50 \mathrm{hrand} 1000 \mathrm{hr}$, but it increased at $500 \mathrm{hr}$.

\section{References}

[1]Nelson, T. W., J. C. Lippold, and M. J. Mills. "Nature and evolution of the fusion boundary in ferritic-austenitic dissimilar metal welds. Part 2-On-cooling transformations." Welding Research 10 (2000): 267-277.

[2]Nelson, T. W., J. C. Lippold, and M. J. Mills. "Investigation of boundaries and structures in dissimilar metal welds." Science and Technology of Welding and Joining 3, no. 5 (1998): 249-255.

[3] Delaunois, Fabienne, Alexis Tshimombo, Victor Stanciu, and VéroniqueVitry. "Monitoring of chloride stress corrosion cracking of austenitic stainless steel: identification of the phases of the corrosion process and use of a modified accelerated test." Corrosion Science 110 (2016): 273-283.

[4]Du, Donghai, Kai Chen, Hui Lu, Lefu Zhang, XiuqiangShi, Xuelian Xu, and Peter L. Andresen. "Effects of chloride and oxygen on stress corrosion cracking of cold worked 316/316L austenitic stainless steel in high temperature water." Corrosion Science 110 (2016): 134-142.

[5]Nowak, G., and A. Rusin. "Shape and operation optimisation of a supercritical steam turbine rotor." Energy conversion and management 74 (2013): 417-425.

[6] Du, Donghai, Kai Chen, Hui Lu, Lefu Zhang, Xiuqiang Shi, XuelianXu, and Peter L. Andresen. "Effects of chloride and oxygen on stress corrosion cracking of cold worked 316/316L austenitic stainless steel in high temperature water." Corrosion Science 110 (2016): 134-142.

[7]El-Zebda, M., M. Shehadeh, and I. Hassan. "Investigating of Erosion Corrosion in Horizontal Steel Pipes with Slurry Seawater Flow." International Review of Chemical Engineering 6, no. 3 (2014): 117-121.

[8]Pan, C., R. Wang, J. Gui, and Y. Shi. "Direct TEM observation of microstructures of the austenitic/carbon steels welded joint." Journal of Materials Science 25, no. 7 (1990): 32813285.

[9]Şimşir, Mehmet, LeventCenkKumruoğlu, and Ali Özer. "An investigation into stainlesssteel/structural-alloy-steel bimetal produced by shell mould casting." Materials \& Design 30, no. 2 (2009): 264-270.

[10]Srinivasan, P. Bala, and MP Satish Kumar. "Microstructural and electrochemical characterization of a thin-section dissimilar stainless steel weld joint." Materials Chemistry and Physics 115, no. 1 (2009): 179-184.

[11] Blasco-Tamarit, E., A. Igual-Muñoz, J. GarcíaAntón, and D. García-García. "Effect of aqueous $\mathrm{LiBr}$ solutions on the corrosion resistance and galvanic corrosion of an austenitic stainless steel in its welded and non-welded condition." Corrosion Science 48, no. 4 (2006): 863-886.

[12]Ul-Hamid, Anwar, and Hani M. Tawancy. "Corrosion of carbon steel caustic header in the presence of chloride ions." Engineering Failure Analysis 16, no. 3 (2009): 825-832. 
[13]Tan, Hua, Zhiyu Wang, Yiming Jiang, Yanze Yang, Bo Deng, Hongmei Song, and Jin Li. "Influence of welding thermal cycles on microstructure and pitting corrosion resistance of 2304 duplex stainless steels." Corrosion Science 55 (2012): 368-377.

[14]El-Zebda, M., M. Shehadeh, and I. Hassan. "Investigating of Erosion Corrosion in Horizontal Steel Pipes with Slurry Seawater Flow." International Review of Chemical Engineering 6, no. 3 (2014): 117-121.

[15]American Society of Mechanical Engineers. "Boiler and pressure vessel Code IX: qualification standard for welding and brazing procedures, welders, brazers, and welding and brazing operators." New York: ASME, (2010).

[16]Aman.y Nagy Kamel.. "Quality Evaluation of Structural Integrity of Welds" Thesis for the Degree of Doctor of Philosophy of Science in Mechanical Production Engineering, Banha University, Shoubra Faculty of Engineering, Egypt, (2012).

[17]Nath, Prekshya, Deepak Kumar Sahu, and ArchanaMallik. "Physicochemical and corrosion properties of sono-electrodeposited $\mathrm{Cu}-\mathrm{Ni}$ thin films." Surface and Coatings Technology 307 (2016): 772-780.

[18]Zhao, Shuangqun, XishanXie, Gaylord D. Smith, and Shailesh J. Patel. "Microstructural stability and mechanical properties of a new nickel-based superalloy." Materials Science and Engineering: A 355, no. 1-2 (2003): 96-105. 